\title{
THE COMPOSITION AND STRUCTURAL FEATURE OF PLANT COMMUNITY IN DIFFERENT KARST STONY DESERTIFICATION AREAS
}

\author{
ANDING, L. ${ }^{1,2}-$ CHUNYAN, G. ${ }^{3}-$ LIFEI, Y. ${ }^{1 *}$ \\ ${ }^{1}$ Guizhou University, Guiyang 550001, China \\ e-mail: anndynlee@126.com; phone: +86-1-39-851-45271 \\ ${ }^{2}$ Institute of Mountain Resources of Guizhou Academy of Sciences \\ Guiyang 550001 China \\ e-mail: anndynlee@126.com; phone: +86-1-39-840-59737 \\ ${ }^{3}$ Guizhou Botanical Garden, Guizhou Academy of Science \\ Guiyang 550001, China \\ e-mail: gchy_922@sina.com; phone: +86-1-35-950-09921 \\ *Corresponding author \\ e-mail: gdyulifei@163.com \\ (Received $10^{\text {th }}$ Apr 2017; accepted $11^{\text {th }}$ Aug 2017)
}

\begin{abstract}
Information on the species composition and community structure of vegetation at different successional stages is useful for understanding successional mechanisms and for selecting species for vegetation recovery. We investigated the composition and structure of plant community in different succession stages by setting 270 sample plots in all 5 types stony desertification areas of Guizhou province, China. The results show that: (1) in the early succession stage of karst rocky desertification area, the environment adaptable species mainly are pioneer species of light-demanding and drought-tolerant. With the succession, species change following a variation trend of "increasing-decreasing-increasing", Shrub stage had the largest number of plant species. (2) There is difference in plant composition in different succession stages of 5 types stony desertification areas. (3) During natural succession stages, the cover degree, predominance degree, and density of plant community represents the horizontal structural feature of karst stony desertification area. The difference in predominance degree and density is considerable, and in certain proportion relation. (4) In early-mid succession stages of plant community, plants are in contagious distribution, while in climax community succession stage, most plants are in random distribution and less are in contagious distribution. From above results, it can be concluded that the variation feature of plant communication in karst stony desertification areas follows certain natural succession law, therefore, species collocation and optimal configuration should be arranged according to natural succession law for control of stony desertification.
\end{abstract}

Keywords: community succession; life form; type of stony desertification; plant arrangement

\section{Introduction}

The total carbonatite outcrop area of China is about $1,300,000 \mathrm{~km}^{2}$, which is distributed in most provinces of China. China's southern region (including Guangxi, Yunnan, Sichuan, Chongqing, Hubei and Hunan provinces based on Guizhou as center) has carbonatite outcrop area of over $540,000 \mathrm{~km}^{2}$, which is featured by the largest outcrop area in 3 linked karst regions, the strongest karst development, the most landscape types, and the most complex ecological environment (Yang et al., 2014; Zhang et al., 2014). Moreover, the aforesaid southern region is the major area where subtropical karst forest locate. Being different from foreign karst regions, the southern karst region of China is mainly composed of hard carbonate rock before triassic period, 
in which the limestone porosity in all geologic ages is lower than $2 \%$, dolomite porosity is generally lower than $4 \%$ with compressive strength under $1000 \mathrm{kpa} / \mathrm{cm}^{2}$ (Jiang et al., 2014). All these characteristics exert great influence to karst development. With the substantial rise of Cenozoic quaternary tectonic movement, the karst topography of carbonate development in all geologic ages becomes more comprehensive, which is distributed in different altitudes, forming the karst landform with world's longest time span and best spatial continuity. Moreover, the karst forest grown in this area has its own particularity in global range, therefore, the ecological study on karst forest in this area is of more important scientific value (Wen et al., 2015).

In the fragile karst ecologic environment, human irrational social economic activities cause prominent human-earth system conflict, vegetation deterioration, water and soil loss, bare rock, land productivity decline or even loss, making ground surface manifested in desert landscape. Such evolution process and outcome is called stony desertification (Jiang et al., 2014). In karst region, stony desertification brings severe impact on the survival, production, and life of rural people, and seriously hinder the sustainable socioeconomic development of this area. However, stony desertification is an inherent and zonal landscape in karst region. For example, the development of karst forest vegetation in Maolan of Guizhou province, which is a primordial forest vegetation, provides references for the recovery of forest vegetation in karst stony desertification area. It is of great significance for stony desertification control to use water, soil, gas, heat in a balance and skillful way in such harsh environment and figure out the succession law and interspecific competitions of plant community in karst region (Liu et al., 2011). Therefore, the species composition and spatial structure of plant community in natural succession stages in karst region should be clearly understood, which provides theoretical basis for species selection in early stage and optimization allocation of stony desertification control.

\section{Profile of Research Area}

Located in eastern part of the Yunnan-Guizhou Plateau, Guizhou province of China has an area of $176,167 \mathrm{~km}^{2}$ including mountainous region and hilly land accounting for 92.5\% of total province area, which is an inland plateau mountainous area with karst development, crosses of mountains and rivers, abundant resources, various nationalities and no plains (Fig. 1). The karst outcrop area of Guizhou province is $109,084.58 \mathrm{~km}^{2}$, accounting for $61.92 \%$ of total province area. In 2011, the stony desertification area of Guizhou province is about $30,200 \mathrm{~km}^{2}$, accounting for $17.16 \%$ of total province area. The rock combination characteristics of Guizhou province can be categorized into 3 major combination types including homogenous carbonate rock combination, combination of carbonate rock intercalated with clastic rock, and interbedded combination of carbonate rock and clastic rock. The homogenous carbonate rock combination can be further divided into homogenous limestone, homogenous dolomite, and mixed combination of limestone and dolomite. The homogenous limestone is mainly distributed in the south, northwest, southwest of Guizhou province, with area 30, $676 \mathrm{~km} 2$, accounting for $17.4 \%$ of total province area. The homogenous dolomite is mainly developed in the northeast of Guizhou province, with area of $22,990 \mathrm{~km} 2$, accounting for $13.1 \%$ of total province area (Tan, 2006).

Research areas were selected in Libo county, Luodian county, Puding county, Wudang district, Xiuwen county, Pan county, Jinsha county, Bijie county, Weining 
county, Sinan county, Yanhe county, Kaili city, Tongren city, Xingyi city, Zhenfeng county (Huajiang valley). The profile of research areas is introduced in Table 1, including place name, longitude and latitude, lithology, stony desertification area, and percentage of stony desertification area to total county (city, district) area.

Table 1. Profile of research areas

\begin{tabular}{|c|c|c|c|c|c|}
\hline $\begin{array}{c}\text { Region(county, } \\
\text { city) }\end{array}$ & $\begin{array}{c}\text { Percentage of } \\
\text { stony } \\
\text { desertification } \\
\text { area } \mathbf{k m}^{2} / \text { total } \\
\text { county (city) } \\
\text { area } \\
\end{array}$ & $\begin{array}{l}\text { Altitude } \\
\text { (m) }\end{array}$ & $\begin{array}{c}\text { Longitude } \\
\text { and latitude }\end{array}$ & $\begin{array}{l}\text { Name of small } \\
\text { sampling site }\end{array}$ & $\begin{array}{c}\text { Lithology } \\
\text { distribution }\end{array}$ \\
\hline Libo county & $658.71 / 27.08$ & 742 & $\begin{array}{l}\mathrm{N} 25^{\circ} 15^{\prime} 41.5^{\prime \prime} \\
\text { E108 } 03^{\circ} 54.9^{\prime \prime}\end{array}$ & Maolan & limestone \\
\hline Luodian county & $1085.26 / 36.06$ & 684 & $\begin{array}{l}\text { N2532'16.9" } \\
\text { E106 } 38^{\prime} 41.5^{\prime \prime}\end{array}$ & $\begin{array}{l}\text { Zhangjiakou, } \\
\text { Bangeng of Yongjin } \\
\text { village }\end{array}$ & limestone \\
\hline Puding county & $390.93 / 35.82$ & 1330 & $\begin{array}{l}\mathrm{N} 27^{\circ} 22^{\prime} 19.1^{\prime \prime} \\
\mathrm{E} 105^{\circ} 44^{\prime} 49.2^{\prime \prime}\end{array}$ & $\begin{array}{c}\text { Houshan, } \\
\text { Miaopuhoushan, } \\
\text { Sankuaitian of } \\
\text { Caojin village }\end{array}$ & limestone \\
\hline Wudang district & 183.03/19.02 & 1081 & 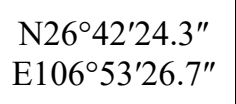 & Xiaba & dolomite \\
\hline Xiuwen county & $250.1 / 23.25$ & 1228 & $\begin{array}{l}\text { N26 } 46^{\circ} 46.8^{\prime \prime} \\
\text { E106 } 32^{\prime} 50.3^{\prime \prime}\end{array}$ & Long chang & dolomite \\
\hline Pan county & $1008.85 / 24.88$ & 2050 & $\begin{array}{l}\mathrm{N} 25^{\circ} 39^{\prime} 10.6^{\prime \prime} \\
\mathrm{E} 104^{\circ} 22^{\prime} 0.4^{\prime \prime}\end{array}$ & $\begin{array}{l}\text { Wangjia grave of } \\
\text { Guanping town }\end{array}$ & limestone \\
\hline Jinsha county & $616.22 / 24.38$ & 1156 & $\begin{array}{l}\mathrm{N} 27^{\circ} 25^{\prime} 16.4^{\prime \prime} \\
\mathrm{E} 106^{\circ} 14^{\prime} 25.4^{\prime \prime}\end{array}$ & $\begin{array}{l}\text { Nongiia cave of } \\
\text { Meng village, } \\
\text { Yangliu of } \\
\text { Chengguan town }\end{array}$ & limestone \\
\hline Bijie county & $902.53 / 26.45$ & 1558 & $\begin{array}{l}\mathrm{N} 27^{\circ} 15^{\prime} 13.7^{\prime \prime} \\
\mathrm{E} 105^{\circ} 19^{\prime} 55.8^{\prime \prime}\end{array}$ & $\begin{array}{l}\text { Stone bridge of } \\
\text { Yachi town }\end{array}$ & limestone \\
\hline Weining county & $1103.91 / 17.53$ & 2430 & $\begin{array}{l}\mathrm{N} 27^{\circ} 07^{\prime} 7.5^{\prime \prime} \\
\mathrm{E} 103^{\circ} 54^{\prime} 8.4^{\prime \prime}\end{array}$ & $\begin{array}{l}\text { Liqi rock of YiNa } \\
\text { town, Xiaojianshan } \\
\text { of Jinzhong town }\end{array}$ & limestone \\
\hline Sinan county & $344.34 / 15.4$ & 655 & $\begin{array}{l}\mathrm{N} 27^{\circ} 52^{\prime} 43.8^{\prime \prime} \\
\mathrm{E} 108^{\circ} 08^{\prime} 20.8^{\prime \prime}\end{array}$ & $\begin{array}{c}\text { Dongkou of } \\
\text { Donghua village, } \\
\text { Yangjiashan of } \\
\text { Xujiaba village }\end{array}$ & dolomite \\
\hline Yanhe county & $711.16 / 28.8$ & 793 & $\begin{array}{l}\mathrm{N} 28^{\circ} 31^{\prime} 11.2^{\prime \prime} \\
\mathrm{E} 108^{\circ} 24^{\prime} 43.0^{\prime \prime}\end{array}$ & $\begin{array}{c}\text { Black water village } \\
\text { (Nanbutuo, } \\
\text { Chaoyang village), } \\
\text { Guanzhou town } \\
\text { (Zhenbian, Qingshan } \\
\text { temple), Siqu town }\end{array}$ & dolomite \\
\hline
\end{tabular}




\begin{tabular}{|c|c|c|c|c|c|}
\hline Tongren city & $256.48 / 17.54$ & 796 & $\begin{array}{l}\mathrm{N} 27^{\circ} 34^{\prime} 26.0^{\prime \prime} \\
\mathrm{E} 105^{\circ} 6^{\prime} 44.0^{\prime \prime}\end{array}$ & $\begin{array}{c}\text { Plum blossom } \\
\text { reservoir of Chadian } \\
\text { town, Niuchangpo of } \\
\text { Yutang village }\end{array}$ & $\begin{array}{l}\text { dolomite } \\
\text { limestone }\end{array}$ \\
\hline Kaili city & $250 / 19.15$ & 756 & $\begin{array}{l}\mathrm{N} 26^{\circ} 31^{\prime} 12.0^{\prime \prime} \\
\mathrm{E} 107^{\circ} 52^{\prime} 42.6^{\prime \prime}\end{array}$ & Yatang, Baiyang & dolomite \\
\hline Xingyi city & $1062.94 / 36.52$ & 1195 & $\begin{array}{l}\mathrm{N} 25^{\circ} 07^{\prime} 22.0^{\prime \prime} \\
\mathrm{E} 104^{\circ} 56^{\prime} 37.4^{\prime \prime}\end{array}$ & $\begin{array}{l}\text { Wanfenglin scenic } \\
\text { entrance of Bajie } \\
\text { town, Yingpanshan } \\
\text { in Pogang nature } \\
\text { reserve of Zhengtun } \\
\text { town }\end{array}$ & limestone \\
\hline $\begin{array}{l}\text { Zhenfeng } \\
\text { county }\end{array}$ & $576.68 / 38.14$ & 565 & $\begin{array}{l}\mathrm{N} 25^{\circ} 39^{\prime} 57.1^{\prime \prime} \\
\mathrm{E} 105^{\circ} 40^{\prime} 16.7^{\prime \prime}\end{array}$ & Banwei, Dingtan & limestone \\
\hline
\end{tabular}

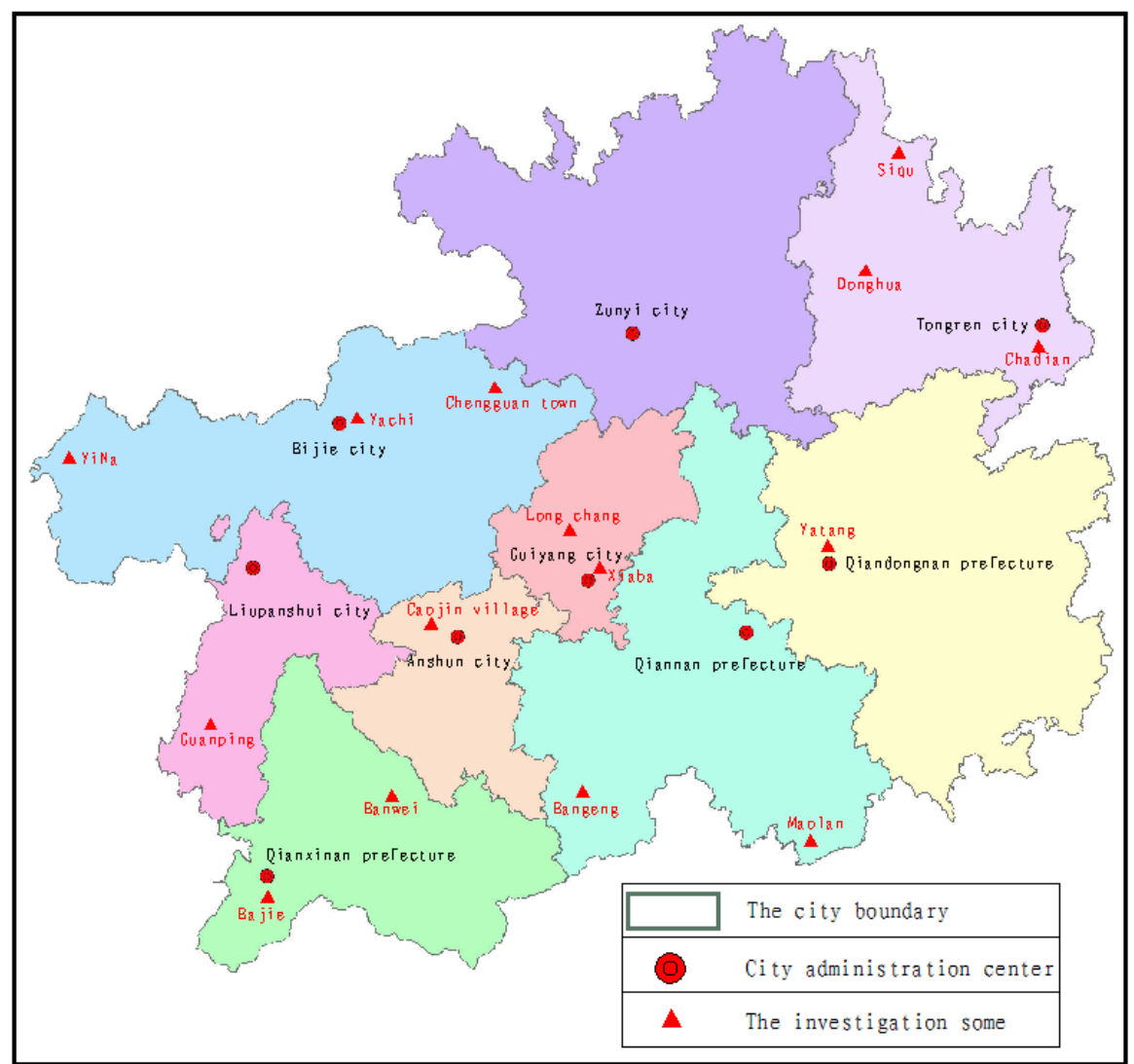

Figure 1. Distribution of research areas in Guizhou province

\section{Research Method}

\section{Sample-plot survey of plant community}

Ecosystem evolution is a long-term course. A natural recovery from degraded grass slope back to climax evergreen and deciduous broad-leaved mixed forest will takes tens or even hundreds of years (Yu, 1998). By setting 270 sample plots in 5 desertification 
areas of Guizhou province, this paper presents investigation on phytocoenology of plant community in different succession stages (Yu et al., 2011) [herbosa succession stage (I), shrub-grass community succession stage(II), brush-shrub community succession stage (III), shrub community succession stage (IV), tree-shrub community succession stage (V), high-forest community succession stage or climax community stage (VI), investigations were conducted 3 times for each stage] using method of substituting spatial sequence for time sequence (Muellerdombois and Ellenberg, 1974). The sample plot areas can be $20 \mathrm{~m}^{2}, 100 \mathrm{~m}^{2}, 100 \mathrm{~m}^{2}, 100 \mathrm{~m}^{2}, 160 \mathrm{~m}^{2}, 400 \mathrm{~m}^{2}$. In each square sample plot, there arranges a $2 \mathrm{~m} \times 2 \mathrm{~m}$ shrub layer quadrat and a $1 \mathrm{~m} \times 1 \mathrm{~m}$ herb layer quadrat. Record the species, quantity, DBH (diameter at breast height), ground diameter, height, crown diameter, cover degree of arbors, shrubs, young trees in each quadrat, and judge whether each plant seeds or sprouts. The species, abundance, height, and cover degree of herbaceous plant were investigated as well.

Annotation: According to the outline of rocky desertification in karst region comprehensive treatment planning (2006y to 2015y), China will be divided into eight desertification control type area, among them, there are five rocky desertification in Guizhou province.

\section{Determination of plant life forms}

Life form: According to life-form system proposed by Raunkiaer, terrestrial plant can be divided into 5 life forms by taking growing height and location of dormant bud and renewal bud in bad seasons as division criterion.

Phanerophyte $(\mathbf{P h})$ : the dormant bud is at least $25 \mathrm{~cm}$ high above the group, which can be divided into 4 sub-forms according to plant height:

Macrophanerophyte (Ma): height $>30 \mathrm{~m}$, for instance megaphanerophyte.

Mesophanerophyte (Me): height 8-30m, for instance microphanerophyte.

Microphanerophyte(Mi): height 2-8m, including microphanerophyte and shrub.

Nanophanerophyte $(\mathrm{N}): 2 \mathrm{~m}>$ height $>25 \mathrm{~cm}$, including shrub and undershrub.

Chamaephyte $(\mathbf{C h})$ : the renewal bud locates above soil surface while under $25 \mathrm{~cm}$, mainly include subshrub herbaceous plants.

Hemicryptophyte (H): the renewal bud locates in soil layer, which will be partially or fully dead on winter ground, mainly including renascent herb.

Cryptophyte (Cr): the renewal bud locates deeply in soil or water, mainly including aquatic renascent herb plant in bulbous, tuberous or rhizomatic types

Therophyte (T): overwintering as a seed. In this paper, phanerophyte was further divided into Evergreen plant (E) and Deciduous plant, (D). For the convenience of distinguishing, Epiphytic plant (Ep) is listed separately in category system

\section{Division method of adapted species}

Community succession is a process where dominant community species changing from one to another. In karst area with complex habitat, there is not one but multiple species that can be adapted to the habitat during the same succession stage (Zhu, 2003). According to the variation of dominant position of main compositional species of deteriorated community during natural recovery process, the adaption level of species can be classified. Specific methods are shown as below:

Based on population as entity, degree of dominance (i.e. important value of population) as attribute, dominance matrix of population during community restoration was established, which means establishing $141 \times 421$ original data matrix using quantity index of 421 plant species in141 quadrats. 


$$
y=\left[\begin{array}{llllllll}
x_{11} & x_{12} & x_{13} & x_{14} & x_{15} & x_{16} & x_{17} & x_{1 j} \\
x_{21} & x_{22} & x_{23} & x_{24} & x_{25} & x_{26} & x_{27} & x_{2 j} \\
x_{31} & x_{32} & x_{33} & x_{34} & x_{35} & x_{36} & x_{37} & x_{3 j} \\
x_{41} & x_{42} & x_{43} & x_{44} & x_{45} & x_{46} & x_{47} & x_{4 j} \\
x_{51} & x_{52} & x_{53} & x_{54} & x_{55} & x_{56} & x_{57} & x_{5 j} \\
x_{61} & x_{62} & x_{63} & x_{64} & x_{65} & x_{66} & x_{67} & x_{6 j} \\
x_{71} & x_{72} & x_{73} & x_{74} & x_{75} & x_{76} & x_{77} & x_{7 j} \\
x_{i 1} & x_{i 2} & x_{i 3} & x_{i 4} & x_{i 5} & x_{i 6} & x_{i 7} & x_{i j}
\end{array}\right]=\left[\begin{array}{lll}
x_{11} & x_{1 j} \\
& \\
x_{i 1} & x_{i j}
\end{array}\right]
$$

Where $i$ represents sample plot, $j$ represents species, $x_{i j}$ represents dominance (important value) of the $j$ th species in the $i$ th quadrat.

After establishing dominance matrix, DCA (Detrended Correspondence Analysis) was adopted for sorting using eigenvector modified based on CA/RA. The primary shaft was divided by DCA into a series of intervals, in which the mean value was set as zero to adjust the coordinate value of the second shaft. This method was effective method for vegetation analysis, which overcame the arch effect of CA/RA, improved sorting accuracy, and realized the results that were the most consistent with Gaussian community model (Zhang, 2004). After that, CANOCO4.5 analysis software was used for analysis and drawing (Zhang et al., 2000). The results aggregated together were merged into a group.

\section{Study on species diversity}

Species diversity was measured using Shannon-wiener diversity index (D):

$$
D=3.3219\left[\lg N-\frac{1}{N}\left(\sum n_{i} \lg n_{i}\right)\right]
$$

community dominance was measured using Simpson index (C):

$$
C=\sum n_{i} \frac{\left(n_{i}-1\right)}{N(N-1)}
$$

Uniformity was measured by uniform index based on Shannon-Wiene diversity index $(\mathrm{J})$ :

$$
J=\frac{\lg N-\frac{1}{N}\left(\sum n_{i} \lg n_{i}\right)}{\left[\lg N-\frac{\alpha(S-\beta) \lg \alpha+\beta(\alpha+1) \lg (\alpha+1)}{N}\right]}
$$

Where $\mathrm{N}$ is the number of species individuals; $\mathrm{n}_{\mathrm{i}}$ is the number of individuals of the ith species; $S$ is the number of species, $\beta$ remainder after dividing $N$ by $S$, ais $(N-\beta) / S$ (ShaoLin, 1996). 


\section{Heterogeneity of community space}

According to geostatistics research method, set $30 \mathrm{~m} \times 30 \mathrm{~m}$ quadrats on main sample plots of herb community, shrub community, high-forest community, and climax community, and then partition quardrats into $1 \mathrm{~m} \times 1 \mathrm{~m}$ adjacent grids. The habitat variables and heterogeneity in each grid was investigated, including mean soil thickness of various microhabitat types (stone-drain, swallet, stone cavern, stone cistern, soil surface, stone surface), as well as mean soil thickness, soil moisture, litter depth and litter coverage in each quadrat. In addition, collect soil sample from each grid, test the $\mathrm{pH}$ value of soil sample, and draw biotope distribution map by measuring scale of 1:500. The investigation was finished at August to September of 2009. The habitat index of soil capacity was proposed in this research, of which the definition is the actual soil volume that can be held in habitat. The soil capacity of each quadrat is the sum of soil capacities of all microhabitats. The soil capacity of each microhabitat is balanced by the product of mean soil thickness and microhabitat distribution area. The distribution area of microhabitat was calculated by paper weighing method according to the distribution map. Soil moisture was measured in field using TDR300 soil-moisture content analyzer, and the soil $\mathrm{pH}$ value was measured in door using PHS-3C acidometer in October, 2009.

As different constants normally have different units and variation degrees, which makes it difficult for practical variable explanation. Therefore, after standardization of variable data by standard deviation, the geostatisticcal common software GS+7.0 was used for variogram analysis, Moran's I analysis, and fractal dimension analysis.

\section{Results and Analysis}

\section{Species composition of plant community in karst stony desertification area during natural succession stage}

Species composition is a necessary element of biotic community. Interspecific coordinated development is related to community succession. The species quantity and composition are very important indexes for evaluating the species diversity, and also the foundation for the stable development of community and ecosystem.

With the succession of community, the species of herb commmunity gradually decrease during recovery stages, while slowly increases in succession stage of highforest, with generally a V-shape variation tendency. In the early recovery stage of community when the environment condition is harsh, species that can be adapted to harsh conditions are mainly light drought-enduring pioneer species, including Pteridium revolutum, Imperata cylindrica var. major, Senecio scandens, Trifolium, Miscanthus si nensis Anderss, Bidens pilosa, Erigeron annuus, Arthraxon hispidus. With the change of environment, there are considerable light drought-enduring woody pioneer species migrating here and settling down. In climax community, succession stage, many light Annual herb species are eliminated by the competition, while some shade-tolerant herb plants are more adapted to such environment, developing into stable climax community and settling down, such as Through investigation, the types of species of herb community in peak-cluster depression of stony desertification area are always in leading position during all recovery stages, wherein the highest value is 76 , while the lowest value is 56. In plateau, trough valley, canyon, fault basin of stony desertification area, there types of species of herb community can be as much as 75, 61, 63, 56, and as less as 37, 31, 34 and 23, respectively (See Fig. 2). 


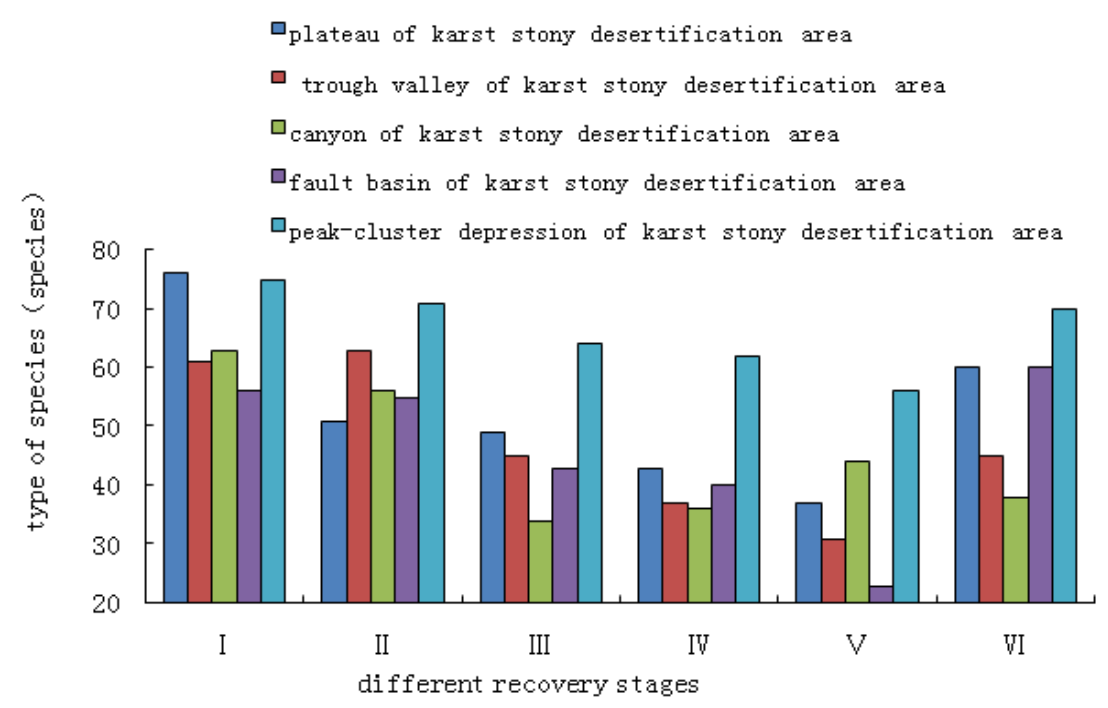

Figure 2. Variation of species of herb plants in karst stony desertification area during different recovery stages

With the succession of community, the species of woody plant shows a variation tendency of "increasing-decreasing-increasing". This is mainly because that in the early recovery stage, the species are less, while with the change of environment, the species of woody plant start to increase and reach saturation in shrub stage. After that due to the limitation of vegetation space, some species are eliminated by competition. In treeshrub transition stage where species competition is the most significant, the early stage of arbor-shrub-grass is also formed, and many species are eliminated because of inadaptation to the transition from light role to shade-tolerance role. In high-forest succession stage, the arbor-shrub-grass layer has been fully formed, shade-tolerance species migrate in and settle down, leading to the increase of species.

According to statistic data, in plateau, trough valley, canyon, fault basin, and peakcluster depression of karst stony desertification area, the species of woody plant can be as much as $118,113,77,42,161$, respectively, wherein the type of species of wood plant in fault basin is relatively less, which is 42 . However, the least number of types of wood plant species in plateau, trough valley, canyon, fault basin, and peak-cluster depression of karst stony desertification are 20, 26, 25, 17, 36, respectively (Fig. 3).

The change law of the entire community is consistent with that of woody plant communities (Fig. 4). The more the type of species is, the more complex the species composition is, the more stable the ecosystem is, and the stronger the resistance to disease and pest is. Therefore, there are diversity of species during disposition of species, including the rosaceous plants, rutaceous plants, and hamamelidaceae plants in early stage as well as fagaceae plant, canella, magnoliaceae plants, theaceae plants in late stage. In the early vegetation recovery stage, it should focus on species selection during artificial disposition of species, while in the mid-late stage, it should focus on species conserving during structural adjustment. 


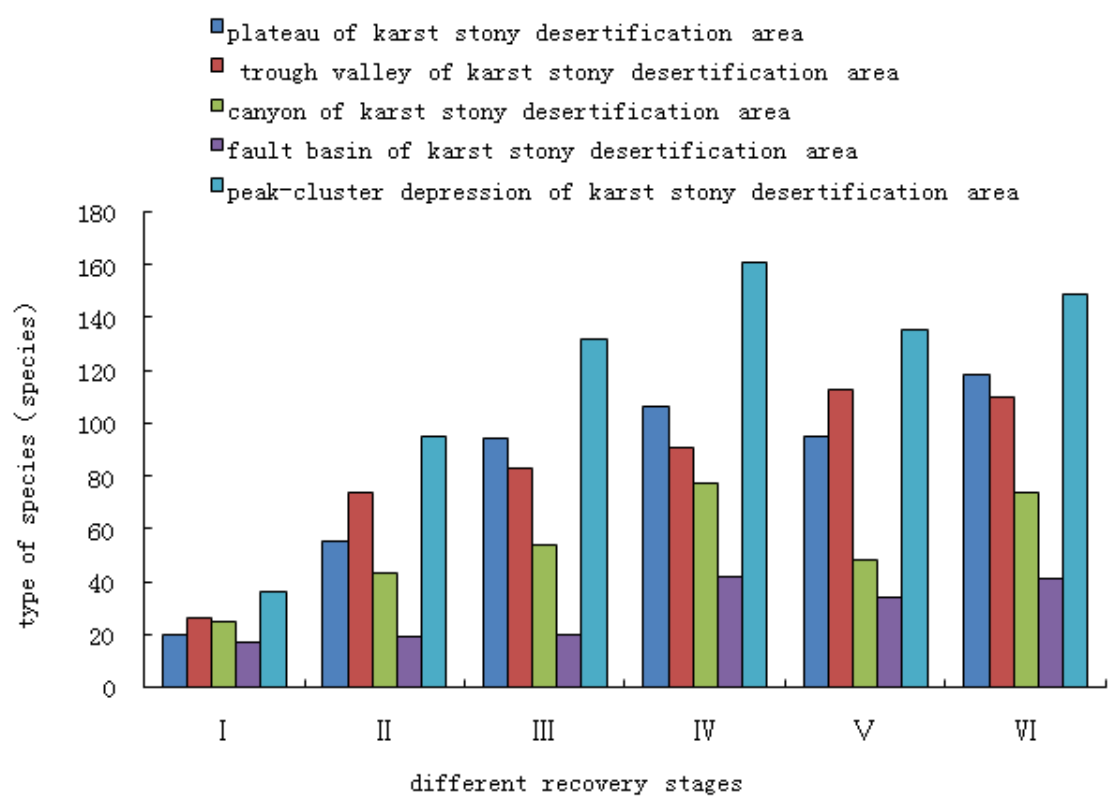

Figure 3. variation of species number of woody plant in stony desertification area during different recovery stages

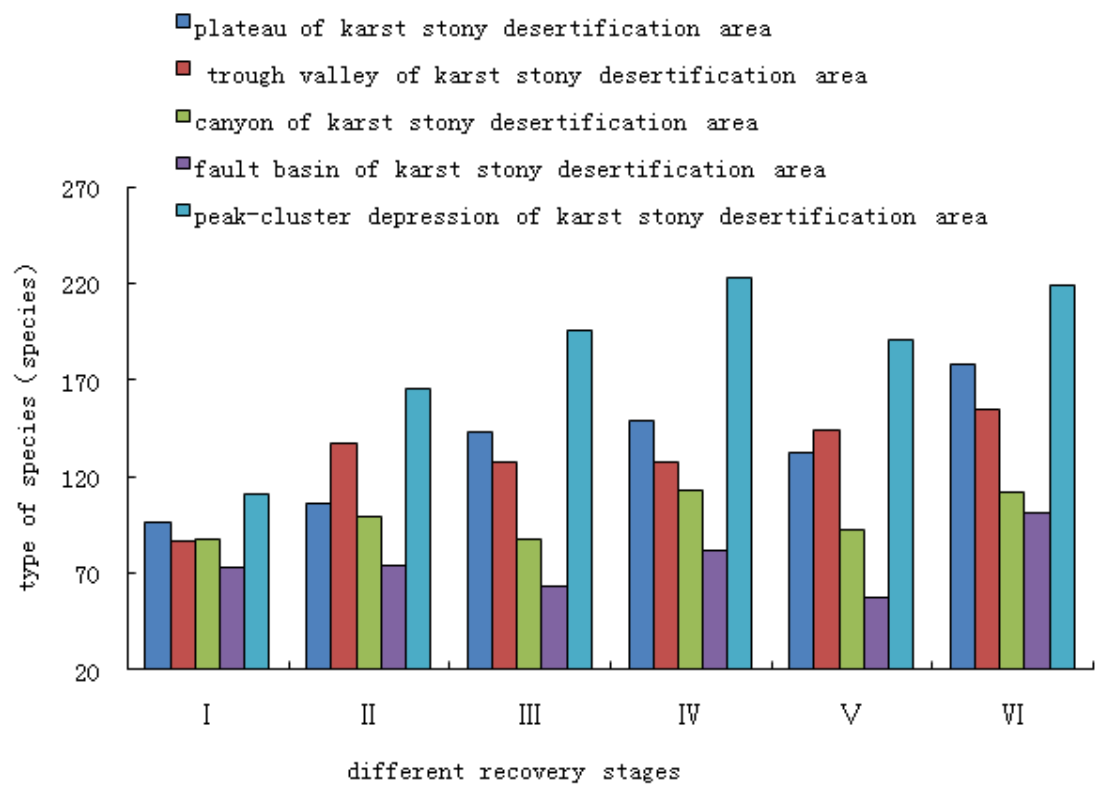

Figure 4. variation of species number of community in stony desertification area during different recovery stages

\section{Life-form composition of plant community in karst stony desertification area during natural succession stage}

Life-form plants at different stony desertification areas include therophyte (T), cryptophyte $(\mathrm{Cr})$, hemicryptophyte $(\mathrm{H})$, chamaephyte $(\mathrm{Ch})$, nanophanerophyte $\mathrm{Ph}(\mathrm{N})$, microphanerophytes $\mathrm{Ph}(\mathrm{Mi})$, mesophanerophyte $\mathrm{Ph}(\mathrm{Me})$, megaphanerophyte $\mathrm{Ph}(\mathrm{Ma})$, Vine plants (EP), evergreen plant (E), deciduous plant (D). However, there is difference 
in life form composition ratio at different stony desertification areas during different succession stages.

In the early succession stage, woody plants are dominant species. With the succession of community, woody plants gradually reduce, and then start to increase by a slight rate in climax community stage. This is because that in the early succession stage where the environment condition is harsh, there is lack of water and severe drought, species that can be adapted to such environment condition are mainly plants with short life span, which is overwintering as a seed, followed by dried-up overground part and underground part regeneration. The therophyte herb plant is featured by large quantity, small individual, and short life span, which is adapted to environment by R-strategy and change in large extent. In the mid-late succession stage, most tree and shrub plants migrate hear, while herb plants gradually decrease, and most remained species are shade-tolerant herb plants, such as pilea notata, pteridophyta and Carex plants. With the successions of community, phanerophyte $(\mathrm{Ph})$ gradually increase, which mainly include $\mathrm{Ph}(\mathrm{N})$ and $\mathrm{Ph}(\mathrm{Mi})$ in early stage as well as $\mathrm{Ph}(\mathrm{Mi})$ and $\mathrm{Ph}(\mathrm{Me})$ in mid-late stage. The variation tendencies of $\mathrm{Ph}(\mathrm{N})$ and $\mathrm{Ph}(\mathrm{Mi})$ are consistent, both of which are first increasing and then decrease; the variation tendency of $\mathrm{Ph}(\mathrm{Me})$ is basically identical to that of $\mathrm{Ph}(\mathrm{Ma})$, both of which are gradually increasing.

In the early succession stage, life form components are mainly herbaceous plant, $\mathrm{Ph}(\mathrm{N})$, and $\mathrm{Ph}(\mathrm{Mi})$, with ratio of $6: 3: 1$; In the middle succession stage, life form components are mainly herbaceous plant, $\mathrm{Ph}(\mathrm{N})$, and $\mathrm{Ph}(\mathrm{Mi})$, with ratio of 3:3:4; In the late succession stage, life form components are mainly herbaceous plant, $\mathrm{Ph}(\mathrm{N}), \mathrm{Ph}(\mathrm{Mi})$, and $\mathrm{Ph}(\mathrm{Me})$, with ratio of 2:3:3:2 (See Table 2).

Table 2. Life form composition ratio of community at different stony desertification areas at early, mid, and late stage of natural succession

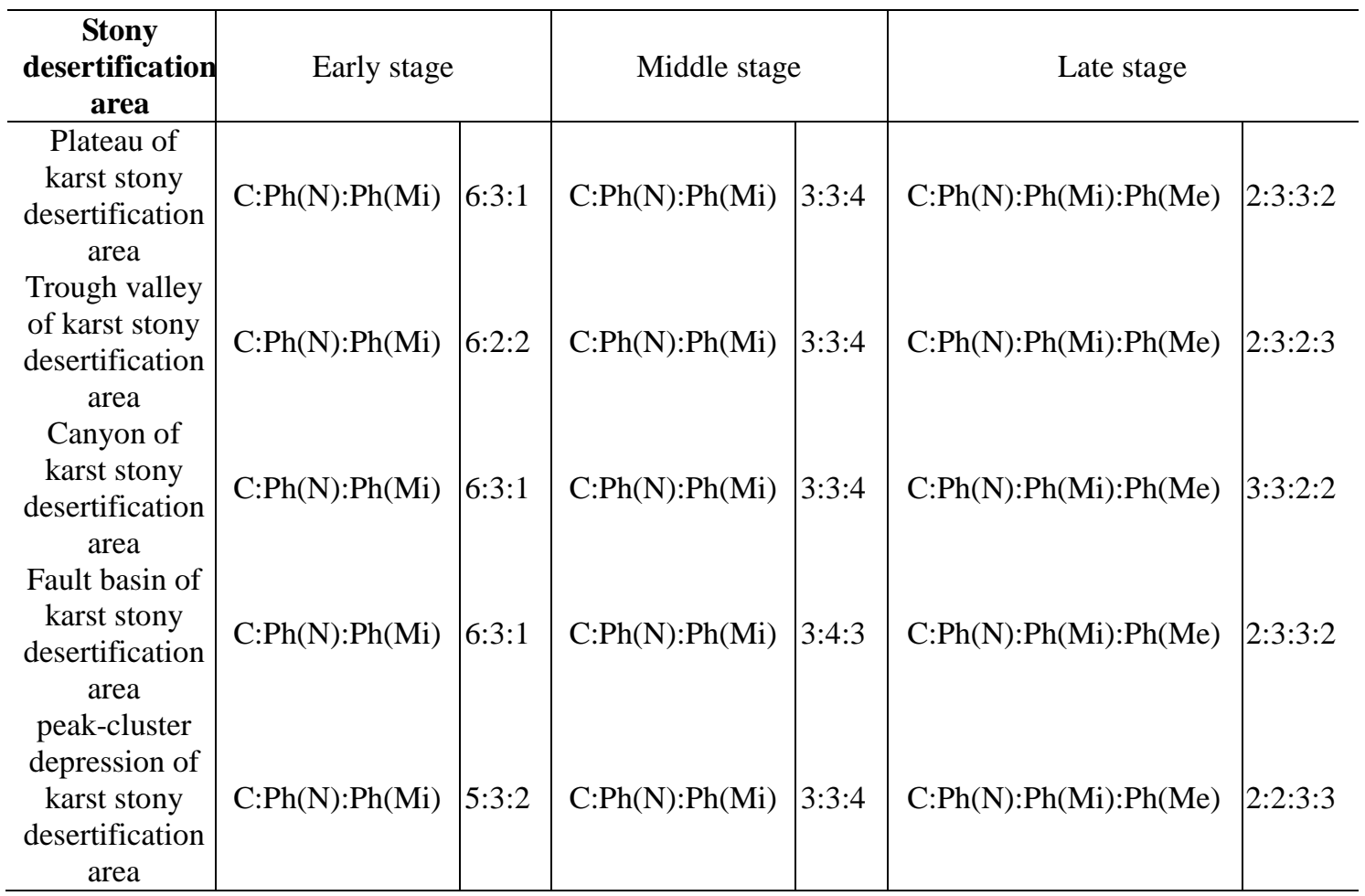

Note: $\mathrm{C}$ represents herbaceous plant, $\mathrm{Ph}(\mathrm{N})$ represents nanophanerophyte, $\mathrm{Ph}(\mathrm{Mi})$ represents microphanerophyte, $\mathrm{Ph}(\mathrm{Me})$ is mesophanerophyte. 


\section{Structural feature of plant community at karst stony desertification area during natural succession stages}

Due to the influence of topographic relief, illumination, and humidity, different species are normally distributed at different areas with different density and cover degree, leading to the difference in horizontal structure of whole community. This paper mainly studied the horizontal structure feature and variation of plant community at karst stony desertification area during different succession stages in term of cover degree, predominance degree, and density.

Herbaceous layer community gradually reduces from grass slope stage to high-forest stage; shrub layer first increases and then decreases, while tree layer gradually increases from V to VI stage. The cover degree of plant community is insignificantly changed, with small difference and basically identical variation tendency among different species, which is generally over $80 \%$. The herbaceous layer, shrub layer, tree layer reach the largest cover degrees of their own when they are at constructive layer.

Although the cover degree of community is merely changed, the cover degrees of herb, shrub, tree layer are significantly changed. The cover degree of herb layer community gradually decreases from $90.6 \%-79 \%$ in grass slope stage to $32-10 \%$ in high-forest stage. In bare rock stage, the cover degree of herb community is even lower, which ranges from 5\% to 20\%; In grass-slope stage, the cover degree of shrub community ranges from $3.9 \%$ to $17 \%$; In shrub community succession stage, the cover degree of shrub layer is the highest, which are $81.7 \%, 80 \%, 85 \%, 80 \%$ and $82.5 \%$ in plateau, trough valley, canyon, fault basin, peak-cluster depression of karst stony desertification area, respectively; the cover degree of high-forest layer is the highest during high-forest succession stage, which are respectively $73.3 \%, 80 \%, 80 \%, 75 \%$ and $71.7 \%$ in above areas, with very small difference (Fig. 5).

The predominance degree of community is mainly manifested by variation of plant thickness accumulation in horizontal direction. The predominance degree of shrub layer community is manifested by variation of plant ground diameter accumulation in horizontal direction, while that of tree layer community is mainly manifested by variation of plant $\mathrm{DBH}$ (at breast height) diameter accumulation in horizontal direction.

In trough valley, fault basin, and plateau of karst stony desertification area, the predominance degree of plant community shows variation tendency of "increasingdecreasing"; while in canyon and peak-cluster depression of karst stony desertification area, the variation of predominance degree of plant community is "increasingdecreasing-decreasing". At canyon of karst stony desertification area in high-forest stage, the predominance degree of shrub layer is high, while the predominance degree of tree layer is low, which indicates such area is dominant by small diameter species during shrub succession stage, while is dominant by large diameter species during tree succession stage. At peak-cluster depression of karst stony desertification area, the predominance degrees of shrub layer and tree layer are both high during high-forest recovery stage, which indicates the large diameter species and small diameter species are both in substantial quantity, and both biomass and stand volume per unit area are in high level (Fig. 6). 


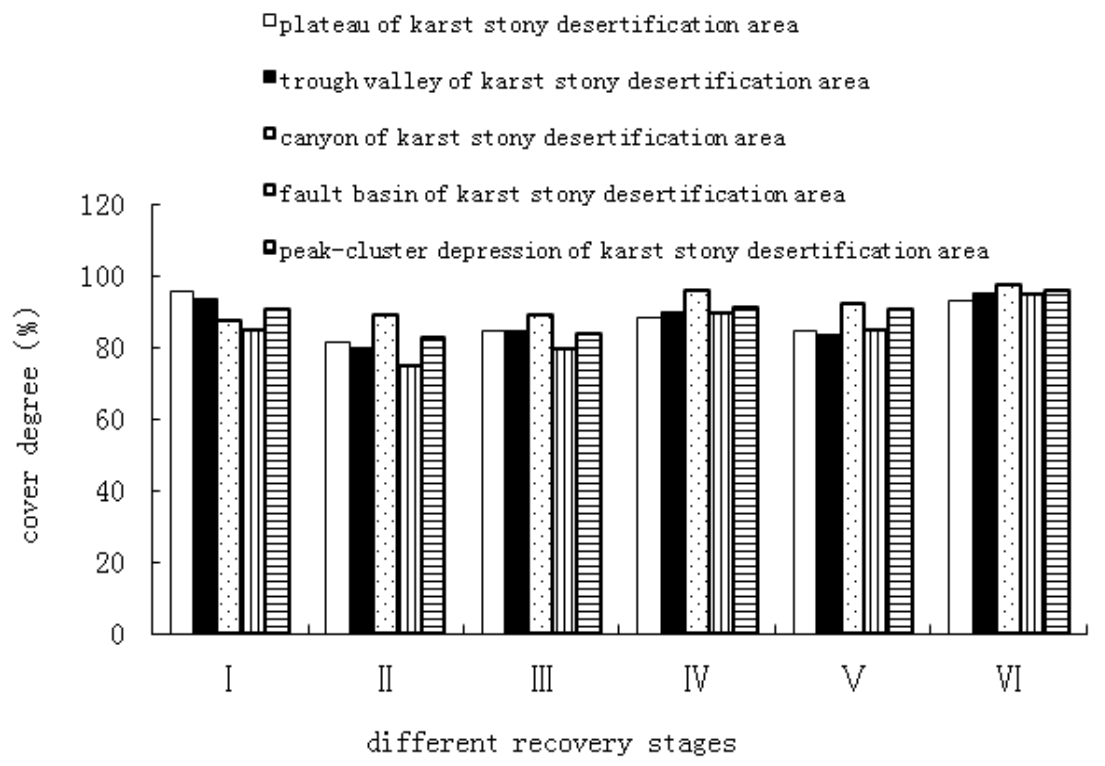

Figure 5. Cover degree of plant community at karst stony desertification area during different succession stages

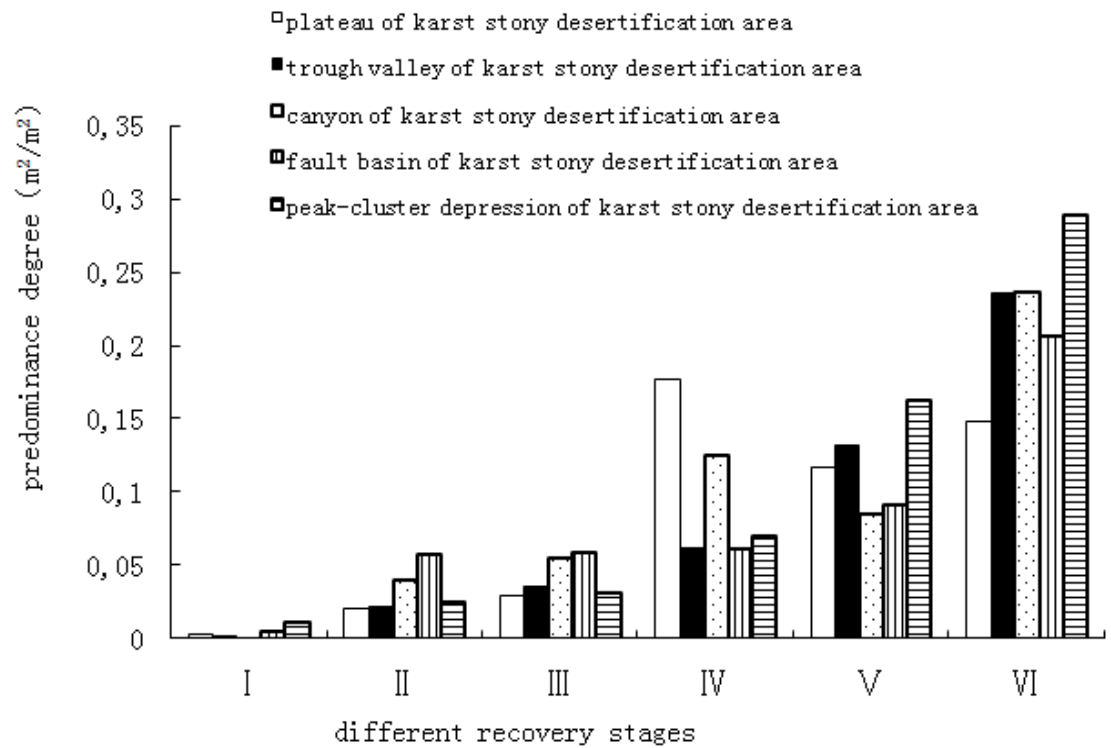

Figure 6. Predominance degree of plant community at karst stony desertification area during different succession stages

In early succession stage, the variation range of predominance of plant community are respectively $0.0019-0.02 \mathrm{~m} 2 / \mathrm{m} 2,0.0012-0.021 \mathrm{~m} 2 / \mathrm{m} 2,0.001-0.0396 \mathrm{~m} 2 / \mathrm{m} 2,0.0053-$ $0.569 \mathrm{~m} 2 / \mathrm{m} 2,0.011-0.0253 \mathrm{~m} 2 / \mathrm{m} 2$ in plateau, trough valley, canyon, fault basin, peakcluster depression of karst stony desertification area.

The density variation of shrub layer is "increasing-decreasing-increasing" with the succession of community. This is due to that in grass slope stage, herb plant is the dominant species; with the migration of woody plants, the herb plants start to decrease while woody plants gradually increase. After reaching a certain quantity, some species 
will be naturally reduced or eliminated due to interspecific competition of vegetation space, while those with strong competence start to enter into tree layer, use large amount of vegetation space, cover the illumination, making the light plants gradually eliminated due to the inadaptation to shady and cool environment. Therefore, the density of community during tree-shrub transition stage is smaller than that during shrub succession stage. After reaching high-forest succession stage, some shade-tolerant species will migrate in, breed on lower light, and species quantity in shrub layer gradually grow. This is the reason why shrub layer density show variation of "increasing-decreasing-increasing". While the density of tree layer at karst stony desertification area shows an increasing tendency.

The density variation of the whole community is consistent with that of shrub layer, which is "increasing-decreasing-increasing"(Fig. 7). This indicates the increase of tree layer is slow, which does not change the variation tendency of the whole community density. Many small shrubs are in aggregated distribution or in clustered distribution, such as myrsine, berberis aggregata, rhamnus heterophylla, chinese spiraea, C.horizontalis perpusillus. In particular, the berberis aggregata in one cluster can be as much as 178 plants. If all plants in one cluster are taken into density, thhen the lowest density of shrub layer in grass-slope stage can account for about 1/4 of the highest density of tree layer in tree succession stage. In addition, there are some sprouting plants including Sichuan hazel, platycarya longipes, Vitex negundo L., bamboo leaves pepper, and small fruit rose root, which are normally in quantity of several plants or dozens of plants. Plants in clustered distribution which are mainly small shrubs show advantage in density.

In this paper, the number of genet of plants in clustered distribution is regarded as 1 . Therefore, in early succession stage, the density of community is relatively smaller, and then gradually increases with the successions, finally reaches the maximum value in the late succession stage. This indicates during community collocation, plant community is in small-density distribution in early succession stage, and then in large-density (including the total density of shrub and tree) distribution in mid-late succession stage. If community structural adjustment is carried out in the late succession stage, it should focus on the density of tree layer, which is $0.48-0.97$ plant $/ \mathrm{m}^{2}$, averaging at 0.65 plant $/ \mathrm{m}^{2}$ in the early stage; $2.16-2.97 \mathrm{plant} / \mathrm{m}^{2}$, averaging at $2.41 \mathrm{plant} / \mathrm{m}^{2}$ in the middle stage; $0.11-0.42 \mathrm{plant} / \mathrm{m}^{2}$, averaging at $0.21 \mathrm{plant} / \mathrm{m}^{2}$ in the late stage (Table 3 ).

Table 3. Densities of constructive species layer at different karst stony desertification areas in the early, mid, late natural succession stage

\begin{tabular}{c|c|c|c}
\hline Stony desertification areas & Early stage & Middle stage & Late stage \\
\hline $\begin{array}{c}\text { Plateau of karst stony desertification } \\
\text { area }\end{array}$ & 0.56 & 2.25 & 0.14 \\
$\begin{array}{c}\text { Trough valley of karst stony } \\
\text { desertification area }\end{array}$ & 0.95 & 2.16 & 0.11 \\
$\begin{array}{c}\text { Canyon of karst stony desertification } \\
\text { area }\end{array}$ & 0.76 & 2.27 & 0.26 \\
$\begin{array}{c}\text { Fault basin of karst stony } \\
\text { desertification area }\end{array}$ & 0.50 & 2.97 & 0.13 \\
$\begin{array}{c}\text { Peak-cluster depression of karst stony } \\
\text { desertification area }\end{array}$ & 0.48 & 2.38 & 0.42 \\
\hline
\end{tabular}




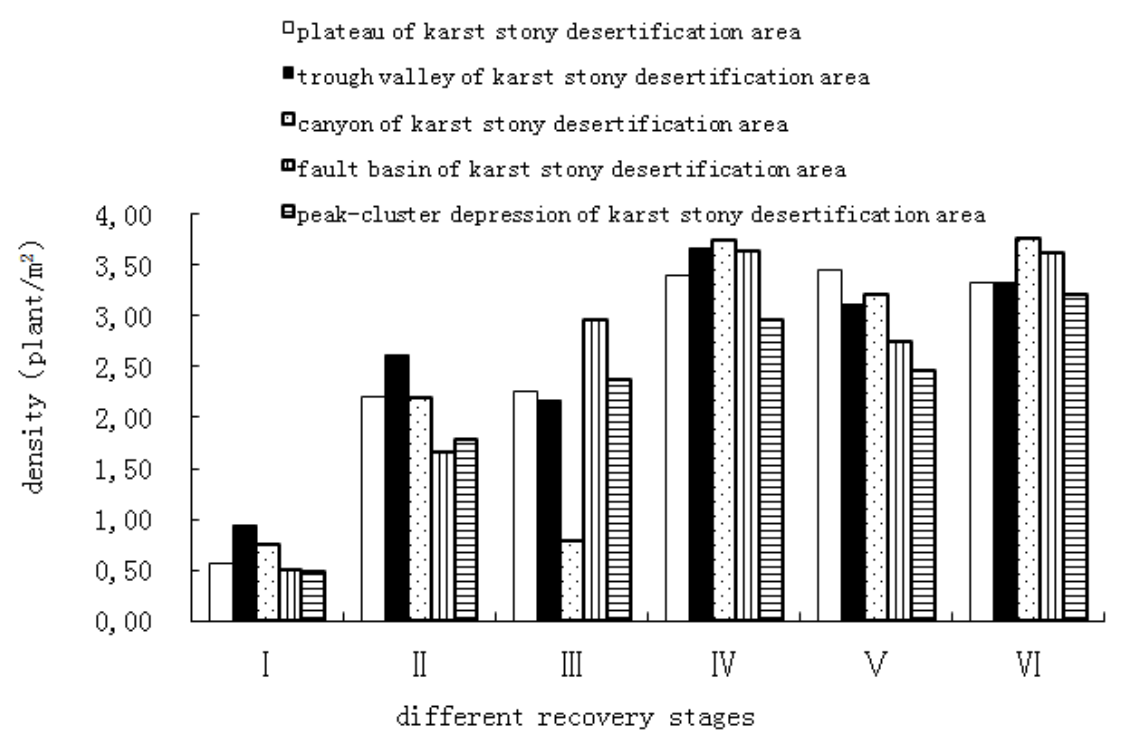

Figure 7. Community densities in karst stony desertification areas at different recovery stages

Through investigating the characteristics of spatial distribution of dominant species at different community layers during different succession stages, it can find that the dominant species in all layers are in aggregated distribution in herb and shrub succession stages, while the dominant species in all community layers during highforest stage is generally in aggregated distribution, but with weaken aggregation intensity and smaller aggregation scale as compared with two former stages, showing variation from aggregated distribution to random distribution in certain degree. In climax succession stage, the dominant species at all community layers is generally in randomly distribution (Figs. 8 and 9).

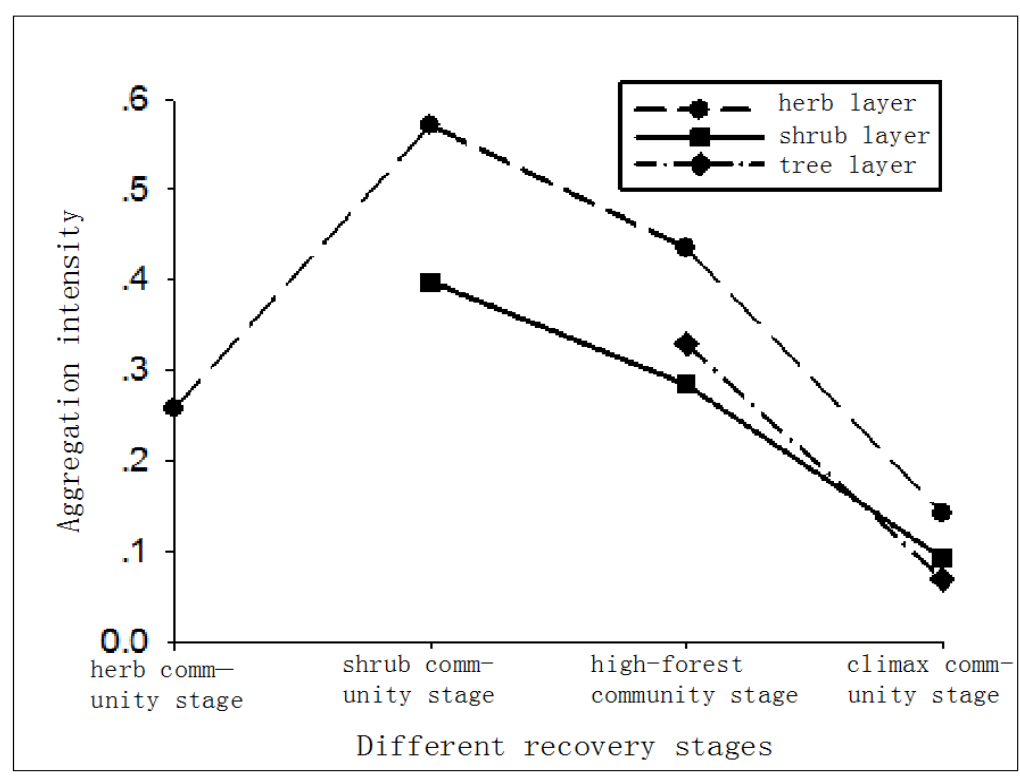

Figure 8. Variation of aggregation intensity of dominant species 


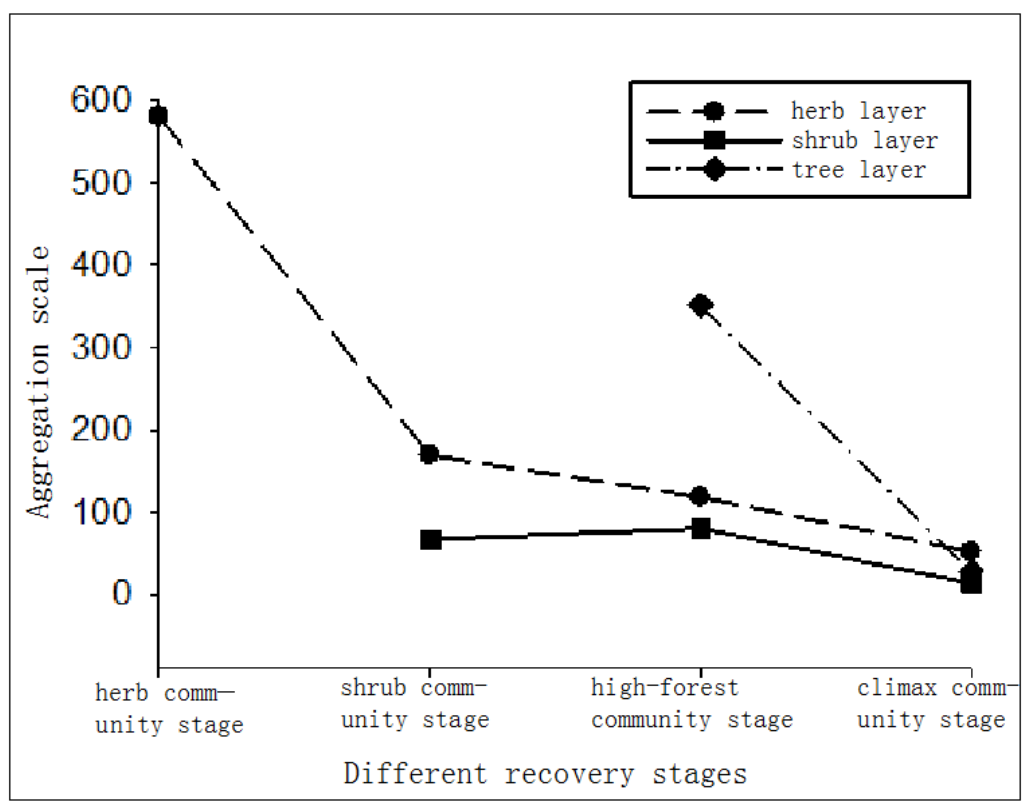

Figure 9. Variation of aggregation scale of dominant species

Therefore, the dominant species at constructive layer in early-mid succession stages are mainly in aggregated distribution, while in the late climax succession stage, they are mainly in random distribution and less are in aggregated distribution. This reveals that the dominant species of plant community at karst stony desertification areas in early stage has small aggregation scale, but larger aggregation intensity which gradually decreases with the succession. The largest aggregation scale of dominant species is relative smaller, therefore the allocation scale of plant community at karst stony desertification areas should be set small.

\section{Disscussions}

The natural succession of plant community follows certain law. The species composition and structure of plant community vary among different stony desertification areas. It has long been suggested that afforestation should be carried out according to local field condition. Through site classification and plant community investigation, it is believed that stony desertification control can be realized by closing the land for reforestation, but also by establishing artificial plant community with consideration on environment condition (site condition), plant ecological adaptability, community composition, community horizontal structure, and community vertical structure.

Liu Xin-ding studied the community composition in red-earth region of southern china during different recovery stages, finding that "the vegetation type and quantity both increase with the succession of recovery stages"(Liu, 2014), which is different from the situation at karst stony desertification area where the species vary in tendency of "increasing-decreasing-increasing". The major different is that the species quantity shows decreasing tendency in tree-shrub recovery stage, which is may be due to ecological environment difference as Guizhou belongs to krast stony desertification area with subtropical humid monsoon climate. 
Similar to karst stony desertification areas, the Loess Plateau of China include therophyte (T), cryptophyte (Cr),hemicryptophyte (H), chamaephyte (Ch), nanophanerophyte $\mathrm{Ph}(\mathrm{N})$, microphanerophytes $\mathrm{Ph}(\mathrm{Mi})$, mesophanerophyte $\mathrm{Ph}(\mathrm{Me})$, megaphanerophyte $\mathrm{Ph}(\mathrm{Ma})$, Vine plants (EP), evergreen plant (E), deciduous plant (D). However, the dominant speice at Loess Plateau of China in the early recovery stage is perennial hemicryptophyte, which is different from therophyte at karst stony desertification areas. This indicates that the vegetation at Loess Plateau of China is influenced by typical temperate climate (Zhang, 2007). Due to the difference in climate and habitat characteristics, the adaptive ways of plant to environment between two area are significantly different, therefore, different vegetation restoration ways should be implemented.

\section{Conclusions}

At karst stony desertification area during early recovery stage when the environment is harsh, species that can be adapted to the environment are mainly light, droughttolerant pioneer species, such as annual herb plants; with the successions of stages, woody plants gradually increase in a variation tendency of "increasing-decreasingincreasing". Till to shrub forest stage, the quantity of woody plants reach the maximum value, and the variation of species composition of whole community is identical to variation of species composition of woody plants.

Five different stony desertification areas all include therophyte (T), cryptophyte $(\mathrm{Cr})$, hemicryptophyte $(\mathrm{H})$, chamaephyte $(\mathrm{Ch})$, nanophanerophyte $\mathrm{Ph}(\mathrm{N})$, microphanerophytes $\mathrm{Ph}(\mathrm{Mi})$, mesophanerophyte $\mathrm{Ph}(\mathrm{Me})$, megaphanerophyte $\mathrm{Ph}(\mathrm{Ma})$, Vine plants (EP), evergreen plant (E), deciduous plant (D). However, there is difference in life form composition ratio during different succession stages. In the early succession stage, herbaceous plant is the dominant species; with the succession of stage, the herbaceous plant gradually decreases, and then increases slowly in climax stage.

During natural succession stages, the cover degree, predominance degree, and density of plant community represents the horizontal structural feature of karst stony desertification area. The cover degrees of plant community at all stony desertification areas are insignificantly different, which is around $80 \%$. Moreover, the cover degrees of herb, shrub, tree layer all reach the maximum when they are in constructive layer. The predominance degrees of community at rough valley, fault basin, and plateau of karst stony desertification area are in variation of "increasing-decreasing" while that at canyon and peak-cluster depression of karst stony desertification are in variation of "increasing-decreasing-increasing". The density of shrub layer is in variation of "increasing-decreasing-increasing", while that of tree layer in increasing variation.

The dominant species at constructive layer in early-mid succession stages are mainly in aggregated distribution, while in the late climax succession stage, they are mainly in random distribution and less are in aggregated distribution. This reveals that the dominant species of plant community at karst stony desertification areas in early stage has small aggregation scale, but larger aggregation intensity which gradually decreases with the succession. The largest aggregation scale of dominant species is relative smaller, therefore the allocation scale of plant community at karst stony desertification areas should be set small. 
Acknowledgements. This research was supported by the National Key Research and Development Program of China (2016YFC050260404), the Key Science and Technology Program of Guizhou Province ([2016]2525), the Key Science and Technology Program of Guangzhou Province (201604020006), the Applied Basic Research Program of Guizhou Province ([2014]200208).

\section{REFERENCES}

[1] Jiang, Z., Lian, Y., Qin, X. (2014): Rocky desertification in Southwest China: Impacts, causes, and restoration. - Earth-Science Reviews 132: 1-12.

[2] Liu, X. D. (2014): Study on Species Composition and Soil Feature at Changting Red Soil Eroded Region during Different Vegetation Restoration Stages. - Master's degree. FuJian Agriculture and Forestry University, FuJian, China.

[3] Liu, Y. G., Liu, C. C., YaFen, W., YongGang, L., Guo, K. (2011): Species composition and community structure at different vegetation successional stages in Puding, Guizhou Province, China. - Chinese Journal of Plant Ecology 35: 1009-1018.

[4] Muellerdombois, D., Ellenberg, H. (1974): Aims and methods of vegetation ecology. John Wiley and Sons, New York, N.Y. 547pp.

[5] Peng, S. L. (1996): Restoration Ecology and Revegetation. - Advances in Ecological Sciences, $15: 26-31$.

[6] Tan, Q. (2006): Analysis of Landscape Pattern and Space Factor of Karst Stony Desertification Area under Different Scales. - Ph.D. The State Laboratory of Environmental Geochemistry, Institute of Geochemistry, Chinese Academy of Science, Gui Yang, China.

[7] Wen, L., Song, T. Q., Du, H., Wang, K., Peng, W. X. (2015): The succession characteristics and its driving mechanism of plant community in karst region, Southwest China. - Acta Ecologica Sinica 35: 5822-5833.

[8] Yang, Q. Y., Jiang, Z. C., Yuan, D. X., Ma, Z. L., Xie, Y. Q. (2014): Temporal and spatial changes of karst rocky desertification in ecological reconstruction region of Southwest China. - Environmental Earth Sciences 72: 4483-4489.

[9] Yu, L. F. (1998): A Study on The Natural Restoration Ecological Proccess of Degraded Karst Forests. - Ph.D., NanJing Forestry University, NanJing.

[10] Yu, L. F., Zhu, S. Q.,Ye, J.Z. (2011): Evaluation Research of Natural Restoration of Degraded Karst Forest. - Scientia Silvae Sinicae, 36: 12-19.

[11] Zhang, J. T. (2004): Quantitative Ecology. - Science Press, Beijing.

[12] Zhang, J. T., Qiu, Y., Chai, B. F. (2000): Analysis of Plant Community Succession at Ynacun Low-middle hills of Lvliang Mountains. - Journal of Plant Resources and Environment 9: 34-39.

[13] Zhang, X., Shang, K., Cen, Y., Shua, T., Sun, Y. (2014): Estimating ecological indicators of karst rocky desertification by linear spectral unmixing method. - International Journal of Applied Earth Observation \& Geoinformation 31: 86-94.

[14] Zhang, Z. G. (2007): Plant Community Characteristics at Abandoned Land of Loess Hilly-gully Region and Environmental Interpretations. - Master's degree, Institute of Soil and Water Consevervation, Chinese Academy of Science, ShanXi, China.

[15] Zhu, S. Q. (2003): Research on Karst Forest ecology III Guizhou. - Science and Technology Publishing Press, Guiyang. 